\title{
Addition of rapamycin and hydroxychloroquine to metronomic chemotherapy as a second line treatment results in high salvage rates for refractory metastatic solid tumors: a pilot safety and effectiveness analysis in a small patient cohort
}

\author{
Kwan-Hwa Chi ${ }^{1,2}$, Hui-Ling Ko ${ }^{1}$, Kai-Lin Yang ${ }^{1}$, Cheng-Yen Lee ${ }^{1}$, Mau-Shin Chi ${ }^{1}$ and \\ Shang-Jyh $\mathrm{KaO}^{3}$ \\ ${ }^{1}$ Department of Radiation Therapy and Oncology, Shin Kong Wu Ho-Su Memorial Hospital, Taipei, Taiwan \\ ${ }^{2}$ School of Medicine and Institute of Biomedical Imaging and Radiological Sciences, National Yang-Ming University, Taipei, \\ Taiwan \\ ${ }^{3}$ Division of Chest Medicine, Shin Kong Wu Ho-Su Memorial Hospital, Taipei, Taiwan \\ Correspondence to: Kwan-Hwa Chi, email: M006565@ms.skh.org.tw \\ Shang-Jyh Kao, email: M001002@ms.skh.org.tw \\ Keywords: rapamycin, hydroxychloroquine, metronomic chemotherapy, autophagy \\ Received: January 15, $2015 \quad$ Accepted: March 18, $2015 \quad$ Published: April 12, 2015
}

This is an open-access article distributed under the terms of the Creative Commons Attribution License, which permits unrestricted use, distribution, and reproduction in any medium, provided the original author and source are credited.

\section{ABSTRACT}

\section{BACKGROUND:}

Autophagy is an important oncotarget that can be modulated during anti-cancer therapy. Enhancing autophagy using chemotherapy and rapamycin (Rapa) treatment and then inhibiting it using hydroxychloroquine (HCQ) could synergistically improve therapy outcome in cancer patients. It is still unclear whether addition of Rapa and HCQ to chemotherapy could be used for reversing drug resistance.

PATIENTS AND METHODS:

Twenty-five stage IV cancer patients were identified. They had no clinical response to first-line metronomic chemotherapy; the patients were salvaged by adding an autophagy inducer (Rapa, $\mathbf{2} \mathrm{mg} / \mathrm{day}$ ) and an autophagosome inhibitor (HCQ, $400 \mathrm{mg} /$ day) to their current metronomic chemotherapy for at least 3 months. Patients included 4 prostate, 4 bladder, 4 lung, 4 breast, 2 colon, and 3 head and neck cancer patients as well as 4 sarcoma patients.

RESULTS:

Chemotherapy was administered for a total of 137 months. The median duration of chemotherapy cycles per patient was 4 months ( $95 \%$ confidence interval, 3-7 months). The overall response rate to this treatment was of $40 \%$, with an $84 \%$ disease control rate. The most frequent and clinically significant toxicities were myelotoxicities. Grade $\geq 3$ leucopenia occurred in 6 patients $(24 \%)$, grade $\geq 3$ thrombocytopenia in $8(32 \%)$, and anemia in $3(12 \%)$. None of them developed febrile neutropenia. Non-hematologic toxicities were fatigue (total $32 \%$, with 1 patient developing grade 3 fatigue), diarrhea (total 20\%, 1 patient developed grade 3 fatigue), reversible grade 3 cardiotoxicity ( 1 patient), and grade $V$ liver toxicity from hepatitis $B$ reactivation (1 patient).

CONCLUSION:

Our results of Rapa, HCQ and chemotherapy triplet combination suggest autophagy is a promising oncotarget and warrants further investigation in phase II studies. 


\section{INTRODUCTION}

Periodical delivery of standard recommended chemotherapy doses in some types of cancers is often associated with significant toxicity without therapeutic gain. The frequent administration of low doses $\left(1 / 10^{\text {th }}\right.$ to $1 / 3^{\text {rd }}$ of maximum tolerated dose, MTD) of certain antineoplastic drugs, known as metronomic chemotherapy, has demonstrated its efficacy and is now getting more popular [1]. The anti-cancer effect occurred principally via an antiangiogenic/anti-vascular mechanism $[1,2]$. Several in vivo experiments have shown that metronomic chemotherapy is more effective in combination with anti-angiogenic, immunotherapeutic, or targeted therapeutic agents $[3,4]$. A growing number of clinical studies have adopted the concept of combined metronomic chemotherapy with anti-angiogenic therapy and have reported an increase in progression-free survival (PFS) in cases of recurrent glioblastoma multiforme [5], cisplatin-refractory ovarian cancer [6], advanced breast cancer [7, 8], non-small cell lung cancer [9], hepatoma [10], and colon cancer [11].

Autophagy is known to promote cancer growth and survival under conditions of nutrient deprivation, hypoxia, or DNA damage caused by chemotherapy [12]. Hydroxychloroquine (HCQ) - a clinically approved antirheumatoid drug - is an analogue of chloroquine (CQ) and acts as a lysosomotropic agent; HCQ inactivates lysosomal enzymes by increasing intralysosomal $\mathrm{pH}$ and significantly inhibiting the last process of autophagy [12]. A greater inhibition of the proliferative activity of various types of cancer has been reported when chemotherapy was combined with the inhibition of autophagy [13]. The premise of inhibiting autophagy to overcome chemotherapy resistance has been clinically investigated [14-19]. Rapa, a clinically approved anti-rejection drug, also known as mammalian target of rapamycin (mTOR) inhibitor, can induce cellular autophagy [20]. Autophagy modulation by combined treatment with an mTOR inhibitor (Rapa) and a lysosome inhibitor (HCQ) was shown to be effective in models of breast cancer, melanoma, and glioma [21-24]. We have found the triplet combination of HCQ, Rapa, and chemotherapy to be synergistic by pushing autophagy through Rapa + chemotherapy and then blocking the final autophagy process through HCQ [25].

A Rapa analogue, everolimus, in combination with HCQ, was found to inhibit growth of endothelial progenitor cells [26]. In this retrospective report, by collecting anecdotal cases in our institute, we found that addition of Rapa and HCQ to a metronomic chemotherapy therapy regimen might be an attractive way to increase sensitization to both the anti-cancer and the antiangiogenesis effect of chemotherapy.

\section{RESULTS}

\section{Patient characteristics}

A total of 46 patients received metronomic chemotherapy from May 2012 to September 2014, and 25 of them fitting the study criteria were included in the analysis (17 women and 8 men). The median age was 62 years (range 47-76). The Eastern Cooperative Oncology Group performance status was 0 in 10 patients and 1 in 15 patients. The characteristics of the patient population are summarized in Table 1.

\section{Tumor responses}

Within the group of 25 evaluable patients, 10 (40\%) experienced PR, and 11 (44\%) had SD. Eightyfour percent of patients experienced clinical benefits for more than 3 months. The clinical characteristics and results of patients who received this treatment strategy are summarized in Table 2. Representative images and tumor marker changes before metronomic chemotherapy, and before and after salvage metronomic chemotherapy are shown in Figures 1 and 2. Many patients documented in the study had non-measurable lesions but had a drop in tumor markers $>50 \%$. The median follow-up time was 11 months (range, 3-28 months). The median duration of salvage treatment was 4 months ( $95 \%$ confidence interval, 3-7 months) before disease progression, contented stop, or refusal to continue treatment. It was very difficult to evaluate the effect of adding Rapa + HCQ to metronomic chemotherapy on the PFS in such a heterogeneous group of patients. Nevertheless, the state of 2 patients progressed from $\mathrm{PD}$ to $\mathrm{PR}$ and that of another 8 patients progressed from SD to PR, following Rapa + HCQ salvage treatment, suggesting an encouraging response to this treatment.

\section{Toxicities}

Data related to non-hematologic toxicity indicated that therapy was well tolerated. As shown in Table 3, 8 patients (32\%) reported grade $\geq 1$ fatigue, including 1 who had grade 3 fatigue and had to discontinue the treatment; diarrhea followed as the second most common toxicity, with $4(16 \%)$ patients exhibiting grade 2 and 1 (4\%) reporting grade 3 diarrhea. Two (8\%) patients had mucositis and 1 (4\%) reported grade 3 nausea/vomiting or renal toxicity. One patient (patient \# 23) had grade 3 cardiotoxicity, with a left ventricle ejection fraction of $35 \%$. The patient recovered after discontinuing all treatment. She had no history of doxorubicin usage. One patient (patient \# 22) experienced grade V hepatitis, which was attributed to the reactivation of previously 

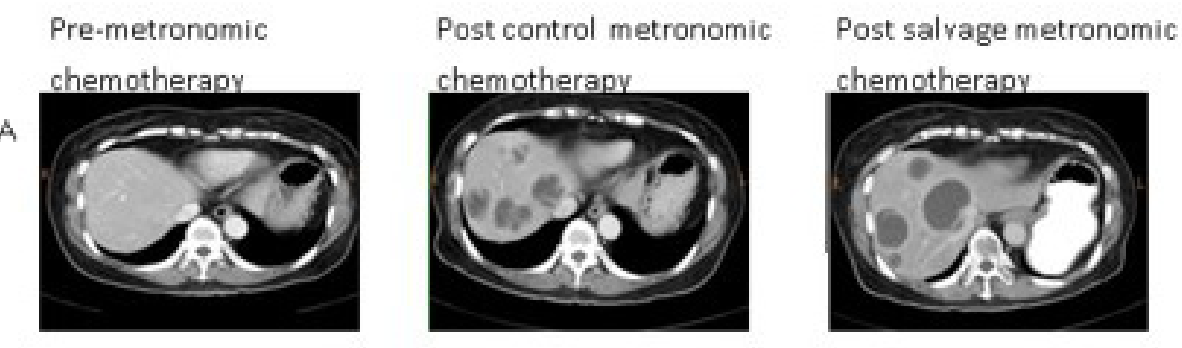

B
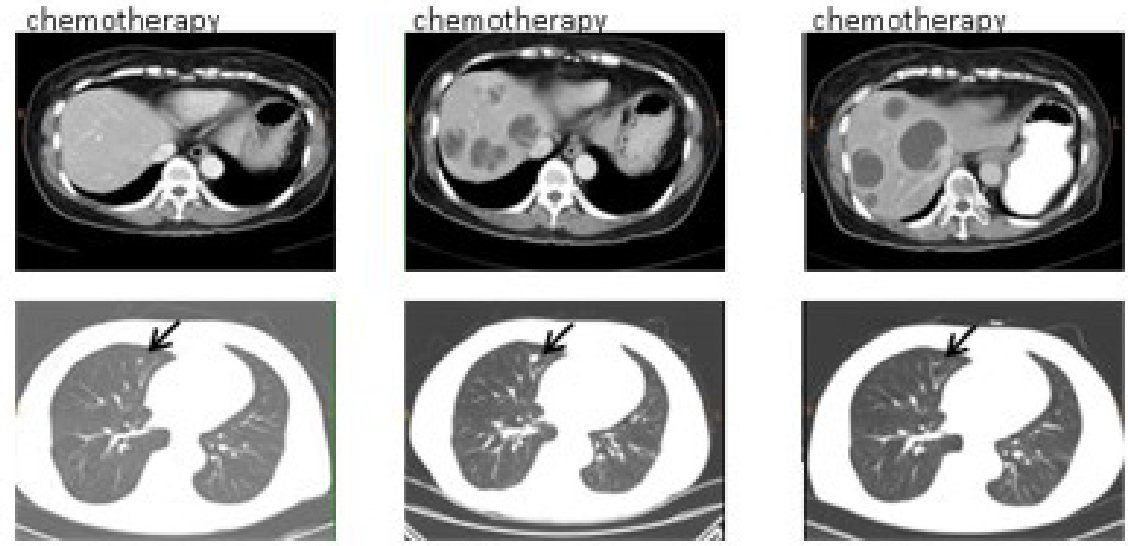

$\mathrm{C}$
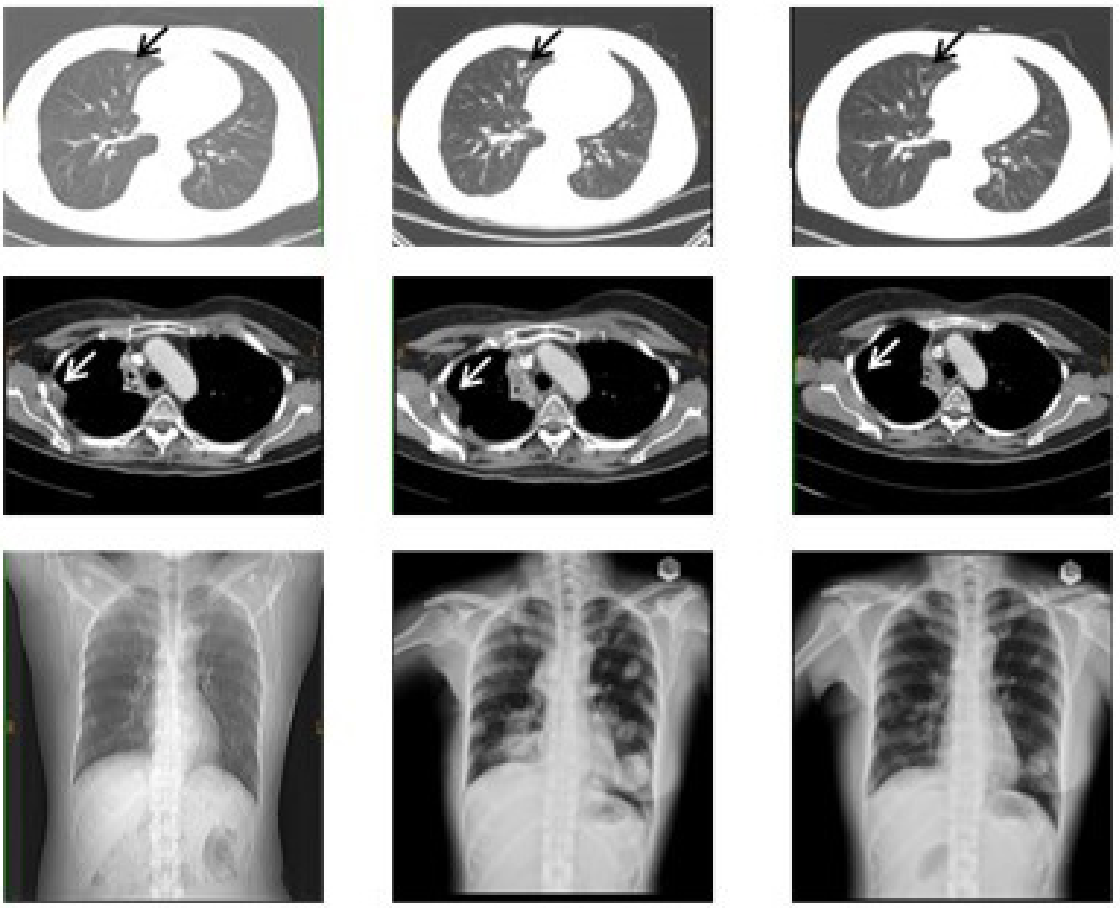

E
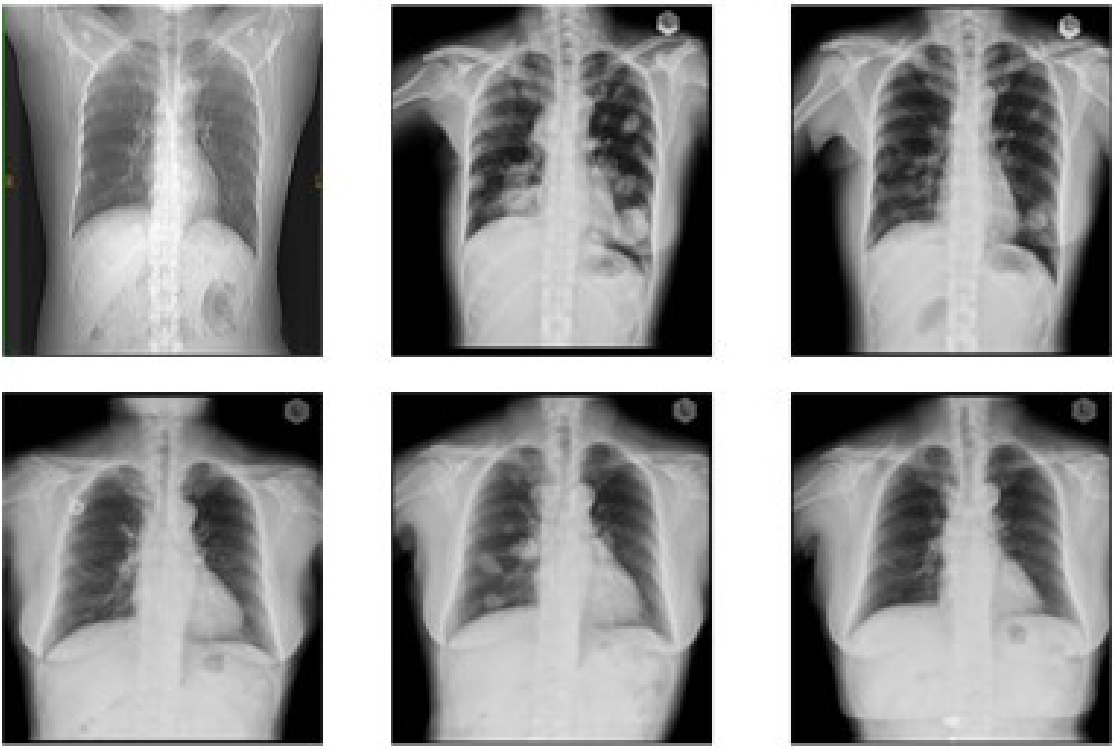

Post control metronomic Post salvage metronomic
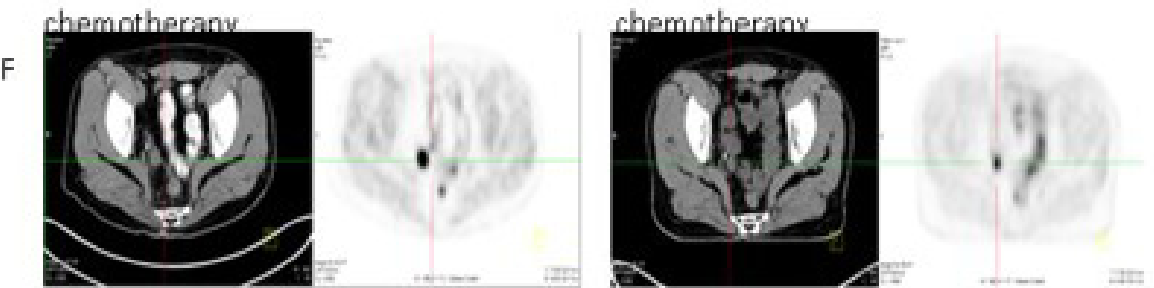

Figure 1: Illustrations of therapeutic responses in representative cases. (A) patient \#6, multiple liver metastases. Although the tumor did not show a reduction in size, the sum of diameters of enhancement regions were reduced by more than $30 \%$, according to the modified RECIST criteria; (B) patient \#8, right upper lung nodular lesion (black arrow); (C) patient \#9, right pleural seeding tumor (white arrow); (D) patient \#19, bilateral multiple lung metastases; (E) patient \#20, bilateral multiple lung metastases; (F) patient \#13, peritoneal seeding in the right pelvic region from positron emission tomography-computed tomography scans before and after salvage metronomic chemotherapy. 
Table 1: Patient Demographics

\begin{tabular}{lc}
\hline \multicolumn{1}{c}{ Characteristics } & Number \\
\hline Total patients & 25 \\
Median age (years, range) & $62(47-76)$
\end{tabular}

Sex

Male

Female

8

17

Diagnosis

$\begin{array}{ll}\text { Prostate cancer } & 4 \\ \text { Bladder cancer } & 4 \\ \text { Lung cancer } & 4 \\ \text { Colorectal cancer } & 2 \\ \text { Breast cancer } & 4 \\ \text { Sarcoma } & 4 \\ \text { Head and Neck cancer } & 3\end{array}$

unnoted hepatitis B virus. She had not been administered prophylactic anti-viral medicine. Myelotoxicity was relatively common, with 8 patients (32\%) developing grade $\geq 3$ thrombocytopenia, 6 patients $(24 \%)$ developing grade $\geq 3$ leucopenia and 3 patients $(12 \%)$ having grade $\geq 3$ anemia. None of the patients developed febrile neutropenia, and they all recovered quickly from myelotoxicities after one to two weeks of treatment interruption.

\section{DISCUSSION}

This is the first report on the addition of Rapa and HCQ to conventional metronomic chemotherapy, which was found to be safe and well tolerated in a variety of cancer types. Most importantly, this chemotherapeutic combination was associated with a $40 \%$ observed response rate and an $84 \%$ disease stabilization in a cohort of patients refractory to their chemotherapy regimen. The significant clinical benefit observed in patients resistant to chemotherapy was unexpected and merits further investigation.

A growing number of clinical studies have shown that the anticancer effect of metronomic chemotherapy is primarily a consequence of its anti-angiogenic effect. Lowdose chemotherapy is preferentially cytotoxic to dividing endothelial cells [30], leading to death of circulating endothelial progenitor cells [31] and a decreased microvessel density [32]. Rapa, although traditionally thought of as an immunosuppressive drug, may also inhibit

- Table 2: Disease status and response after addition of Rapa + HCQ to metronomic chemotherapy

\begin{tabular}{|c|c|c|c|c|c|c|c|c|c|c|}
\hline Patient \# & Tumor type & $\begin{array}{l}\text { Performance } \\
\text { status }\end{array}$ & $\begin{array}{l}\text { Previous therapy } \\
\text { after initial } \\
\text { treatment failure }\end{array}$ & $\begin{array}{l}\text { Control metronomic } \\
\text { chemotherapy }\end{array}$ & $\begin{array}{l}\text { Control treatment } \\
\text { duration (months) }\end{array}$ & $\begin{array}{l}\text { Response to control } \\
\text { metronomic } \\
\text { chemotherapy }\end{array}$ & $\begin{array}{c}\text { Best response to } \\
\text { Rapa + HCQ } \\
\text { salvage } \\
\text { chemotherapy }\end{array}$ & $\begin{array}{c}\text { Evaluation } \\
\text { method }\end{array}$ & $\begin{array}{l}\text { Treatment } \\
\text { duration } \\
\text { (months) }\end{array}$ & $\begin{array}{c}\text { Current } \\
\text { status }\end{array}$ \\
\hline 1 & $\begin{array}{l}\text { Prostate ca with bone } \\
\text { meta }\end{array}$ & 1 & Hormone therapy & $\begin{array}{c}\text { Cyproterone } 1 \text { \# bid Docetaxel } 40 \\
\text { mg q2wk }\end{array}$ & 4 & PD & $\mathrm{SD}$ & $\begin{array}{l}\mathrm{PSA}>50 \% \\
\text { decline }\end{array}$ & 6 & A \\
\hline 2 & $\begin{array}{l}\text { Prostate ca with bone } \\
\text { meta }\end{array}$ & 1 & Hormone therapy & $\begin{array}{l}\text { Cyproterone I\# bid Docetaxel } 40 \\
\mathrm{mg} \mathrm{q} 2 \mathrm{wk}\end{array}$ & 2 & PD & SD & $\mathrm{PSA}>50 \%$ & 3 & A \\
\hline 3 & $\begin{array}{l}\text { Prostate ca with LN, } \\
\text { bone meta }\end{array}$ & 1 & Hormone therapy & $\begin{array}{l}\text { Cyproterone } 1 \text { \# bid Docetaxel } 40 \\
\qquad \mathrm{mg} \mathrm{q}^{2} \mathrm{wk}\end{array}$ & 3 & SD & SD & $\begin{array}{l}\mathrm{PSA}>50 \% \\
\text { decline }\end{array}$ & 3 & A \\
\hline 4 & $\begin{array}{l}\text { Prostate ca with LN } \\
\text { meta }\end{array}$ & 0 & Hormone therapy & $\begin{array}{c}\text { Cyproterone } \mathrm{l} \text { \# bid Docetaxel } 40 \\
\mathrm{mg} \mathrm{q} 2 \mathrm{wk}\end{array}$ & 3 & SD & PR & RECIST & 3 & A \\
\hline 5 & $\begin{array}{l}\text { Bladder ca with lung } \\
\text { meta }\end{array}$ & 1 & - & $\begin{array}{l}\text { Carboplatin } 150 \mathrm{mg}+ \\
\text { Gemcitabine } 1400 \mathrm{mg} \text { q2 wk }\end{array}$ & 4 & PD & SD & RECIST & 8 & A \\
\hline 6 & $\begin{array}{l}\text { Bladder ca with liver } \\
\text { meta }\end{array}$ & 1 & $\begin{array}{c}\text { Cisplatin } 50 \mathrm{mg} / \mathrm{m}^{2} \text {; } \\
\text { D1 +gemcitabine } \\
1000 \mathrm{mg} / \mathrm{m}^{2} \mathrm{D}, 8 \\
\mathrm{q}^{3 \mathrm{w}}\end{array}$ & $\begin{array}{c}\text { Carboplatin } 150 \mathrm{mg}+ \\
\text { Gemcitabine } 1400 \mathrm{mg} \mathrm{q} 2 \mathrm{wk}\end{array}$ & 3 & PD & PR & $\begin{array}{c}\text { RECIST } \\
+ \text { CFR } 21.1 \\
\text { decline }>50 \%\end{array}$ & 3 & A \\
\hline 7 & $\begin{array}{l}\text { Bladder ca with neck } \\
\qquad \text { LN meta }\end{array}$ & 0 & - & $\begin{array}{l}\text { Carboplatin } 150 \mathrm{mg}+ \\
\text { Gemcitabine } 1400 \mathrm{mg} \mathrm{q} 2 \mathrm{wk}\end{array}$ & 4 & PD & PD & RECIST & 3 & A \\
\hline
\end{tabular}


Lung ca,

adenocarcinoma with

brain, pleural meta

Lung ca, squamous

carcinoma with pleura

effusion

Lung ca,

adenocarcinoma with

multiple meta

Lung $\mathrm{ca}$,

adenocarcinoma with

multiple meta

Rectal ca with peritoneal

seeding

Colon ca with lung and

pelvic meta

Breast ca with liver and

abdomen LN meta

Breast ca with bone

meta

Breast ca with chest wall

recurrence

Breast ca with bone and

chest wall recurrence

Phylloides tumor with

lung meta

Fibrosarcoma with lung

meta

Sarcoma, nonspecific

with LN meta

Leiomyosarcoma of

22

uterus with pelvic

recurrence
TKI, RT, Cisplatin+ $\quad$ Vinorelbine $30 \mathrm{mg}$ p.o. weekly,

Pemetrexed Docetaxel $40 \mathrm{mg} \mathrm{q} 2 \mathrm{wk}$

RT, Cisplatin+

Gemcitabine

Vinorelbine $30 \mathrm{mg}$ p.o. weekly,

TKI, RT, Cisplatin+

Pemetrexed

Vinorelbine $30 \mathrm{mg}$ p.o. weekly,

Docetaxel $40 \mathrm{mg} \mathrm{q} 2 \mathrm{wk}$

Pemetrexed

Vinorelbine $30 \mathrm{mg}$ p.o. weekly,

Docetaxel $40 \mathrm{mg}$ q2wk

Capecitabine 1 \# bid +Irinotecan

FOLFIRI

$100 \mathrm{mg} / \mathrm{m}^{2} \mathrm{q} 2 \mathrm{wk}$

Bevacizumab

Capecitabine 1 \# bid +Irinotecan

$100 \mathrm{mg} / \mathrm{m}^{2} \mathrm{q} 2 \mathrm{wk}$

Vinorelbine $30 \mathrm{mg}$ p.o. weekly,

Capecitabine 1\# bid, Gemcitabin $800 \mathrm{mg} / \mathrm{m}^{2} \mathrm{q} 2 \mathrm{wk}$

Vinorelbine $30 \mathrm{mg}$ p.o. weekly,

Tamoxifen

Capecitabine $1 \#$ bid, Gemcitabine

$800 \mathrm{mg} / \mathrm{m}^{2} \mathrm{q} 2 \mathrm{wk}$

Vinorelbine $30 \mathrm{mg}$ p.o. weekly,

CAF, Docetaxel

Capecitabine 1\# bid, Gemcitabine

$800 \mathrm{mg} / \mathrm{m}^{2} \mathrm{q} 2 \mathrm{wk}$

Vinorelbine $30 \mathrm{mg}$ p.o. weekly,

Capecitabine 1\# bid, Gemcitabine

$800 \mathrm{mg} / \mathrm{m}^{2} \mathrm{q} 2 \mathrm{wk}$

Cyclophosphamide (50)1\# qod,

Etoposide(50) 1\# qod,

Gemcitabine $1400 \mathrm{mg} \mathrm{q} 2 \mathrm{wk}$

Cyclophosphamide (50)1\# qod,

Etoposide(50) 1\# qod,

Gemcitabine $1400 \mathrm{mg}$ q2wk

Cyclophosphamide (50)1\# qod,

Etoposide(50) 1\# qod,

Gemcitabine $1400 \mathrm{mg} \mathrm{q} 2 \mathrm{wk}$

Cyclophosphamide (50)1\# qod,

Etoposide(50) 1\# qod,

Gemcitabine $1400 \mathrm{mg}$ q2wk
$\mathrm{SD}$

PD

RECIST

PR

CEA declin

$>50 \%$

RECIST

RECIST

SD

CEA declin

$>50 \%$

RECIST

SD

PR

RECIST

Tumor marke

$>50 \%$ decline

RECIST

Tumor marke

SD

$>50 \%$ decline

RECIST

RECIST

SD

RECIST

SD

PR

RECIST

D

PD

PD

RECIST

PD

PD

RECIST

4

D 


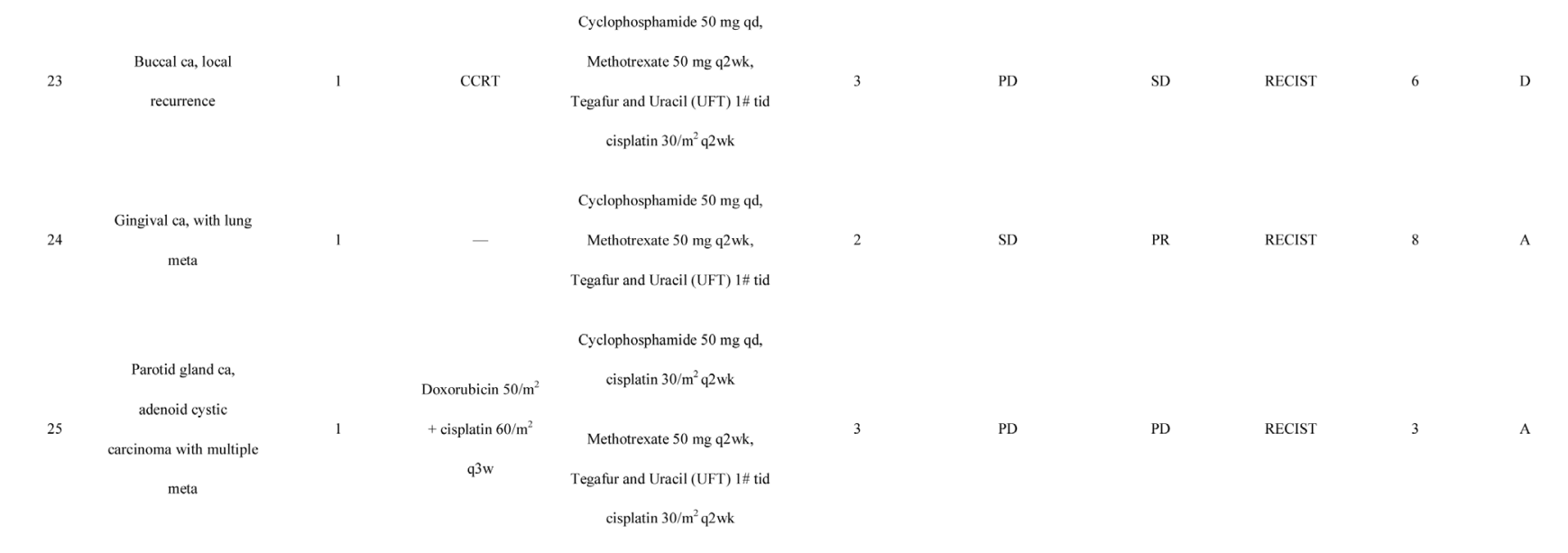

Abbreviations: Ca, cancer; meta, metastasis; bid, twice a day; tid, three times a day; qd, every day; qod, every other day; q2wk, every 2 weeks; LN, lymph node(s); CCRT, concomitant chemoradiotherapy; TKI, tyrosine kinase inhibitor; RT, radiotherapy; FOLFIRI, Irinotecan with fluorouracil and folinic acid; FOLFOX, oxaliplatin with fluorouracil and folinic acid; CAF, 5-fluorouracil, doxorubicin, cyclophosphamide.
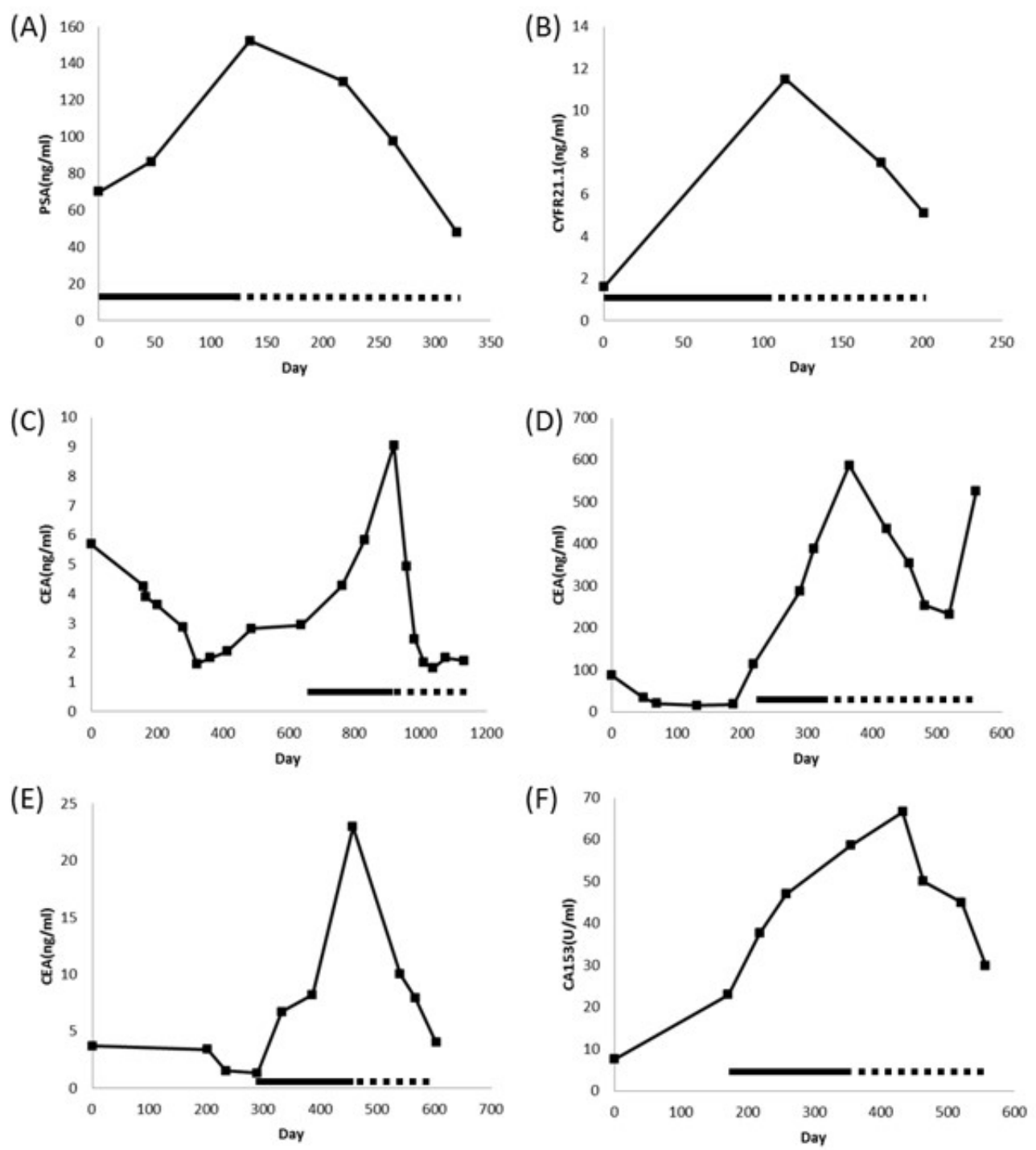

Figure 2: Representative plots of serum tumor markers versus time. (A) patient \#1; (B) patient \#6; (C) patient \#9; (D) patient $\# 11$; (E) patient \#14; (F) patient \#16. - Control metronomic chemotherapy; ..... Rapa/HCQ + metronomic chemotherapy. 
Table 3: Chemotherapy toxicity

\begin{tabular}{|c|c|c|c|c|}
\hline & \multicolumn{2}{|c|}{$\begin{array}{l}\text { Metronomic } \\
\text { chemotherapy }\end{array}$} & \multicolumn{2}{|c|}{$\begin{array}{c}\text { Rapa }+ \text { HCQ }+ \text { metrono } \\
\text { mic chemotherapy }\end{array}$} \\
\hline & \multicolumn{2}{|c|}{$\mathrm{N}(\%)$} & \multicolumn{2}{|c|}{$\mathrm{N}(\%)$} \\
\hline & Grade 3 & Grade 4 & Grade 3 & Grade 4 \\
\hline Leucopenia & $3(12 \%)$ & 0 & $6(24 \%)$ & 0 \\
\hline Thrombocytopenia & $2(8 \%)$ & 0 & $7(28 \%)$ & $1(4 \%)$ \\
\hline Anemia & $2(8 \%)$ & 0 & $3(12 \%)$ & 0 \\
\hline Nausea/Vomiting & 0 & 0 & $1(4 \%)$ & 0 \\
\hline Mucositis & 0 & 0 & $1(4 \%)$ & 0 \\
\hline Diarrhea & 0 & 0 & $1(4 \%)$ & 0 \\
\hline Asthenia & 0 & 0 & $1(4 \%)$ & 0 \\
\hline Hepatic toxicity & 0 & 0 & 0 & $1(4 \%)$ \\
\hline Renal toxicity & 0 & 0 & 0 & 0 \\
\hline Cardiac toxicity & 0 & 0 & $1(4 \%)$ & 0 \\
\hline Skin rash & 0 & 0 & 0 & 0 \\
\hline Retinopathy & 0 & 0 & 0 & 0 \\
\hline
\end{tabular}

tumor growth and have anti-angiogenic effects [33]. Recently, CQ has also been reported not only to reduce tumor growth, but also to improve tumor angiogenesis in a mechanism independent of autophagy [34]. CQ normalized tumor vessel structure and perfusion function, improved hypoxia, and reduced tumor invasion through endosomal Notch 1 trafficking and signaling in endothelial cells [34]. The synergistic effect of everolimus and CQ combination on endothelial cell apoptosis was found to be linked to the down-regulation of ERK1/2 phosphorylation in these cells [26]. Clearly, the combination of metronomic chemotherapy, Rapa and HCQ must activate common antiangiogenic pathways. The CT attenuation of Hounsfield Units in bladder cancer with liver metastases as shown in Figure 1 is typical evidence of anti-angiogenic effects after combination treatment [35].

It is not yet known whether the positive results obtained using this strategy is caused solely by additive anti-angiogenic effects or by modulation of autophagy. Several phase II clinical trials have examined the potential benefits of adding either mTOR inhibitors (Rapa, everolimus, tenolimus) or HCQ (autophagy-lysosome inhibitor) to conventional chemotherapy in the treatment of patients with malignant gliomas [36, 37], non-Hodgkin lymphomas [38], sarcoma [39], melanoma [15, 16], breast [40], non-small cell lung [41, 42], esophageal [43], and head and neck cancers [44]. Neither strategy had resulted in impressive results. This is the first clinical report describing concomitant use of Rapa, HCQ, and chemotherapy in various cancer types. The results of this 
self-controlled study indicated that such combinations were not only effective, but also could reverse drug resistance. The autophagy inducer and lysosomal inhibitor in combination with chemotherapy seem to work synergistically. The doses of Rapa (2 mg/day) and HCQ (400 mg/day) were derived from conventional therapeutic doses used in rheumatoid arthritis, kidney transplantation, or treatment of lymphangioleiomyomatosis [45-47]. These doses are not MTD, especially for HCQ, which was reportedly used at a dose of $1200 \mathrm{mg}$ /day in combination with temozolomide for the treatment of solid tumors [8]. The dosages of these drugs were not obtained through serial phase I studies of different chemotherapeutic combinations, and therefore, the doses of these drugs could be increased further prior to committing to a phase II trial. Another weakness of this report is the lack of pharmacodynamic assays in tumor tissues or peripheral mononuclear cells. Indeed, the targeted signaling pathways (autophagy or angiogenesis) might not have been modified by these drugs. We have conducted a molecular imaging study in sarcoma patients before and after 2 weeks of treatment with Rapa (2 mg/day) and HCQ (400 mg/day) on the basis of reports that cancer-associated fibroblasts could be potential oncotargets [48].

Although a clinical benefit rate of $84 \%$ in this selectively chosen patient cohort seems impressive, additional randomized phase II trials are required before the claim of actual clinical benefits can be accepted. Nevertheless, the real benefit of dual modulation of autophagy might be even more impressive in combination with standard dose chemotherapy.

\section{MATERIALS AND METHODS}

\section{Patient selection}

Patients chosen for analysis were required to have incurable metastatic/recurrent disease and no clinical response from current metronomic chemotherapy regardless of the primary tumor type. Patients needed to continue the same metronomic chemotherapy in addition to Rapa (2 mg qd) and HCQ (400 mg qd) as salvage treatment. They needed to have an Eastern Cooperative Oncology Group performance status of 0 to 1; a life expectancy of at least 3 months before salvage treatment, and either have at least one single site of measurable (twodimensional) disease or serial and continuous ( $>3$ monthly measurement) elevated tumor markers (at least twice the upper limit) in patients with non-measurable lesions. Patients were excluded if treatment with metronomic therapy and salvage therapy was shorter than 12 weeks, unless there was a radiographic confirmation of disease progression. This retrospective study was approved by our institutional review board (IRB).

\section{Treatment}

Patients were treated using different metronomic regimen based on their disease type: cyproterone, $50 \mathrm{mg}$ orally 1 tablet twice daily (1\# bid), and, docetaxel, $40 \mathrm{mg}$ per body intravenously (i.v.) every 2 weeks (q2w) for prostate cancer; capecitabine, $500 \mathrm{mg} 1$ \# bid, vinorelbine, $30 \mathrm{mg}$ orally once a week (qw), and gemcitabine, $800 \mathrm{mg} /$ $\mathrm{m}^{2}$ i.v. $\mathrm{q} 2 \mathrm{w}$ for breast cancer; vinorelbine, $30 \mathrm{mg}$ orally qw plus docetaxel, $40 \mathrm{mg}$ per body i.v. q2w for lung cancer; capecitabine, $500 \mathrm{mg} 1$ \# bid, and irinotecan, 100 $\mathrm{mg} / \mathrm{m}^{2}$ i.v. $\mathrm{q} 2 \mathrm{w}$ for colorectal cancer; carboplatin, 150 mg per body, plus gemcitabine, $1400 \mathrm{mg}$ per body i.v. q2w for bladder cancer; cyclophosphamide, $50 \mathrm{mg}$ orally every other day (qod), methotrexate, $50 \mathrm{mg}$ orally qw, tegafur and uracil (UFT), 1\# three times a day (tid), and cisplatin, $30 \mathrm{mg} / \mathrm{m}^{2}$ i.v. q2w for head and neck cancers; cyclophosphamide, $50 \mathrm{mg}$ orally qod, etoposide, $50 \mathrm{mg}$ orally qod, and gemcitabine, $1400 \mathrm{mg}$ per body i.v. q2w for sarcoma. Rapa (2 mg) and HCQ (400 mg) treatments were started following the physician's suggestion the patients' signing an agreement for the additional treatment. The dose of Rapa, HCQ was choosing from conventional therapeutic doses used in rheumatoid arthritis, kidney transplantation. The metronomic chemotherapy schedule was followed as given above. There was no dose modification of Rapa, HCQ, or chemotherapy. The only treatment interruption was scheduled when grade $\geq 3$ myelotoxicity was observed, with a maximum delay of 3 weeks being allowed. Supportive care agents such as anti-emetics, antibiotics, loperamide, growth factors, transfusions, or fluid supply were administered as indicated.

Treatment was discontinued with the development of grade IV non-myelotoxicity, patient intolerance, or disease progression. Treatment-related toxicity was assessed every 2 weeks. Toxicity was scored according to the Common Terminology Criteria for Adverse Events (CTCAE) v4.0 [27]. Response was evaluated using chest radiography, computed tomography (CT), or positron emission tomography-computed tomography, which were obtained in principle every 2 to 3 months. Tumor markers were assessed every 1 to 3 months. Response Evaluation Criteria in Solid Tumor (RECIST) v1.1 guidelines were used as follows: complete response (CR, disappearance of measurable disease without development of new lesions, with tumor markers dropping to normal range), partial response $(\mathrm{PR}$, at least $30 \%$ reduction in the sum of the longest diameters measured at disease sites or enhanced area), progressive disease (PD, at least 20\% increase in the sum of the longest diameter measured disease sites or appearance of new lesions), and stable disease (SD, if determination did not meet criteria of $\mathrm{CR}, \mathrm{PR}$, or $\mathrm{PD}$, or those patients with tumor markers decline of $>50 \%$ in non-measurable lesions) [28, 29]. The radiologic evaluation of the response was obtained by consensus 
following meeting of the three principle investigators (K.H.C., K.L.Y., and H.L.K.). Clinical benefit rate was defined as the percentage of patients without disease progression for more than 3 months.

\section{CONFLICTS OF INTEREST}

All authors declare no conflicts of interest.

\section{REFERENCES}

1. Romiti A, Cox MC, Sarcina I, Di Rocco R, D'Antonio C, Barucca V and Marchetti P. Metronomic chemotherapy for cancer treatment: a decade of clinical studies. Cancer chemotherapy and pharmacology. 2013; 72:13-33.

2. Vacca A, Iurlaro M, Ribatti D, Minischetti M, Nico B, Ria $\mathrm{R}$, Pellegrino A and Dammacco F. Antiangiogenesis is produced by nontoxic doses of vinblastine. Blood. 1999; 94:4143-4155.

3. Bello L, Carrabba G, Giussani C, Lucini V, Cerutti F, Scaglione F, Landre J, Pluderi M, Tomei G, Villani R, Carroll RS, Black PM and Bikfalvi A. Low-dose chemotherapy combined with an antiangiogenic drug reduces human glioma growth in vivo. Cancer research. 2001; 61:7501-7506.

4. Hermans IF, Chong TW, Palmowski MJ, Harris AL and Cerundolo V. Synergistic effect of metronomic dosing of cyclophosphamide combined with specific antitumor immunotherapy in a murine melanoma model. Cancer research. 2003; 63:8408-8413.

5. Vredenburgh JJ, Desjardins A, Herndon JE, 2nd, Marcello J, Reardon DA, Quinn JA, Rich JN, Sathornsumetee S, Gururangan S, Sampson J, Wagner M, Bailey L, Bigner DD, Friedman AH and Friedman HS. Bevacizumab plus irinotecan in recurrent glioblastoma multiforme. Journal of clinical oncology : official journal of the American Society of Clinical Oncology. 2007; 25:4722-4729.

6. Barber EL, Zsiros E, Lurain JR, Rademaker A, Schink JC and Neubauer NL. The combination of intravenous bevacizumab and metronomic oral cyclophosphamide is an effective regimen for platinum-resistant recurrent ovarian cancer. Journal of gynecologic oncology. 2013; 24:258-264.

7. Dellapasqua S, Bertolini F, Bagnardi V, Campagnoli E, Scarano E, Torrisi R, Shaked Y, Mancuso P, Goldhirsch A, Rocca A, Pietri E and Colleoni M. Metronomic cyclophosphamide and capecitabine combined with bevacizumab in advanced breast cancer. Journal of clinical oncology : official journal of the American Society of Clinical Oncology. 2008; 26:4899-4905.

8. Garcia-Saenz JA, Martin M, Calles A, Bueno C, Rodriguez L, Bobokova J, Custodio A, Casado A and Diaz-Rubio E. Bevacizumab in combination with metronomic chemotherapy in patients with anthracycline- and taxanerefractory breast cancer. Journal of chemotherapy. 2008; 20:632-639.
9. Marquette CL, Grant, S.C., DeShazo, M., Reddy, V., Cantor, A., Miley, D., Jerome, M., Robert, F. Phase II study of metronomic chemotherapy (MC) with bevacizumab (B) in patients with advanced nonsquamous non-small cell lung cancer (NSNSCLC). Journal of clinical oncology : official journal of the American Society of Clinical Oncology. 2013; 31((supply)):abstr. 8057.

10. Hsu CH, Shen YC, Lin ZZ, Chen PJ, Shao YY, Ding YH, Hsu C and Cheng AL. Phase II study of combining sorafenib with metronomic tegafur/uracil for advanced hepatocellular carcinoma. Journal of hepatology. 2010; 53:126-131.

11. Kelley RK, Hwang J, Magbanua MJ, Watt L, Beumer JH, Christner SM, Baruchel S, Wu B, Fong L, Yeh BM, Moore AP, Ko AH, Korn WM, Rajpal S, Park JW, Tempero MA, et al. A phase 1 trial of imatinib, bevacizumab, and metronomic cyclophosphamide in advanced colorectal cancer. British journal of cancer. 2013; 109:1725-1734.

12. Mizushima N, Levine B, Cuervo AM and Klionsky DJ. Autophagy fights disease through cellular self-digestion. Nature. 2008; 451:1069-1075.

13. Yang ZJ, Chee CE, Huang S and Sinicrope FA. The Role of Autophagy in Cancer: Therapeutic Implications. Molecular Cancer Therapeutics. 2011; 10:1533-1541.

14. Mahalingam D, Mita M, Sarantopoulos J, Wood L, Amaravadi RK, Davis LE, Mita AC, Curiel TJ, Espitia CM, Nawrocki ST, Giles FJ and Carew JS. Combined autophagy and HDAC inhibition: a phase I safety, tolerability, pharmacokinetic, and pharmacodynamic analysis of hydroxychloroquine in combination with the HDAC inhibitor vorinostat in patients with advanced solid tumors. Autophagy. 2014; 10:1403-1414.

15. Rangwala R, Chang YC, Hu J, Algazy KM, Evans TL, Fecher LA, Schuchter LM, Torigian DA, Panosian JT, Troxel AB, Tan KS, Heitjan DF, DeMichele AM, Vaughn DJ, Redlinger M, Alavi A, et al. Combined MTOR and autophagy inhibition: phase I trial of hydroxychloroquine and temsirolimus in patients with advanced solid tumors and melanoma. Autophagy. 2014; 10:1391-1402.

16. Rangwala R, Leone R, Chang YC, Fecher LA, Schuchter LM, Kramer A, Tan KS, Heitjan DF, Rodgers G, Gallagher M, Piao S, Troxel AB, Evans TL, DeMichele AM, Nathanson KL, O'Dwyer PJ, et al. Phase I trial of hydroxychloroquine with dose-intense temozolomide in patients with advanced solid tumors and melanoma. Autophagy. 2014; 10:1369-1379.

17. Vogl DT, Stadtmauer EA, Tan KS, Heitjan DF, Davis LE, Pontiggia L, Rangwala R, Piao S, Chang YC, Scott EC, Paul TM, Nichols CW, Porter DL, Kaplan J, Mallon G, Bradner JE, et al. Combined autophagy and proteasome inhibition: a phase 1 trial of hydroxychloroquine and bortezomib in patients with relapsed/refractory myeloma. Autophagy. 2014; 10:1380-1390.

18. Rosenfeld MR, Ye X, Supko JG, Desideri S, Grossman SA, Brem S, Mikkelson T, Wang D, Chang YC, Hu J, 
McAfee Q, Fisher J, Troxel AB, Piao S, Heitjan DF, Tan KS, et al. A phase I/II trial of hydroxychloroquine in conjunction with radiation therapy and concurrent and adjuvant temozolomide in patients with newly diagnosed glioblastoma multiforme. Autophagy. 2014; 10:1359-1368.

19. Poklepovic A and Gewirtz DA. Outcome of early clinical trials of the combination of hydroxychloroquine with chemotherapy in cancer. Autophagy. 2014; 10:1478-1480.

20. Vignot S, Faivre S, Aguirre D and Raymond E. mTORtargeted therapy of cancer with rapamycin derivatives. Annals of oncology : official journal of the European Society for Medical Oncology / ESMO. 2005; 16:525-537.

21. Seront E, Boidot R, Bouzin C, Karroum O, Jordan BF, Gallez B, Machiels JP and Feron O. Tumour hypoxia determines the potential of combining mTOR and autophagy inhibitors to treat mammary tumours. British journal of cancer. 2013; 109:2597-2606.

22. Xie X, White EP and Mehnert JM. Coordinate autophagy and mTOR pathway inhibition enhances cell death in melanoma. PloS one. 2013; 8:e55096.

23. Fan QW, Cheng C, Hackett C, Feldman M, Houseman BT, Nicolaides T, Haas-Kogan D, James CD, Oakes SA, Debnath J, Shokat KM and Weiss WA. Akt and autophagy cooperate to promote survival of drug-resistant glioma. Science signaling. 2010; 3:ra81.

24. Bray K, Mathew R, Lau A, Kamphorst JJ, Fan J, Chen J, Chen H-Y, Ghavami A, Stein M, DiPaola RS, Zhang D, Rabinowitz JD and White E. Autophagy Suppresses RIP Kinase-Dependent Necrosis Enabling Survival to mTOR Inhibition. PLoS ONE. 2012; 7:e41831.

25. Wang YS HY, Fong WL, Chi MS, Chi KH. Abstract 5611: A synthetic lethality combination with chloroquine and rapamycin on chemosensitization. Cancer research. 2012; 72(8 Supplement \%U http://cancerres.aacrjournals.org/ content/72/8_Supplement/5611.abstract):5611.

26. Grimaldi A, Balestrieri ML, D’Onofrio N, Di Domenico G, Nocera C, Lamberti M, Tonini G, Zoccoli A, Santini D, Caraglia M and Pantano F. The Synergistic Effect of Everolimus and Chloroquine on Endothelial Cell Number Reduction Is Paralleled by Increased Apoptosis and Reduced Autophagy Occurrence. PLoS ONE. 2013; 8:e79658.

27. Cancer Therapy Evaluation Program. NCI. Common Terminology Criteria for Adverse Events (CTCAE) v4.0. Data files and Related Documents. http://evsncinihgov/ftp1/ CTCAE/Abouthtml. 2011; Accessed October 21.

28. Eisenhauer EA, Therasse P, Bogaerts J, Schwartz LH, Sargent D, Ford R, Dancey J, Arbuck S, Gwyther S, Mooney M, Rubinstein L, Shankar L, Dodd L, Kaplan R, Lacombe D and Verweij J. New response evaluation criteria in solid tumours: revised RECIST guideline (version 1.1). Eur J Cancer. 2009; 45:228-247.

29. Lencioni R and Llovet JM. Modified RECIST (mRECIST) assessment for hepatocellular carcinoma. Seminars in liver disease. 2010; 30:52-60.

30. Bocci G, Nicolaou KC and Kerbel RS. Protracted lowdose effects on human endothelial cell proliferation and survival in vitro reveal a selective antiangiogenic window for various chemotherapeutic drugs. Cancer research. 2002; 62:6938-6943.

31. Bertolini F, Paul S, Mancuso P, Monestiroli S, Gobbi A, Shaked Y and Kerbel RS. Maximum tolerable dose and low-dose metronomic chemotherapy have opposite effects on the mobilization and viability of circulating endothelial progenitor cells. Cancer research. 2003; 63:4342-4346.

32. Klement G, Huang P, Mayer B, Green SK, Man S, Bohlen P, Hicklin D and Kerbel RS. Differences in therapeutic indexes of combination metronomic chemotherapy and an anti-VEGFR-2 antibody in multidrug-resistant human breast cancer xenografts. Clinical cancer research : an official journal of the American Association for Cancer Research. 2002; 8:221-232.

33. Guba M, von Breitenbuch P, Steinbauer M, Koehl G, Flegel S, Hornung M, Bruns CJ, Zuelke C, Farkas S, Anthuber M, Jauch KW and Geissler EK. Rapamycin inhibits primary and metastatic tumor growth by antiangiogenesis: involvement of vascular endothelial growth factor. Nature medicine. 2002; 8:128-135.

34. Maes H, Kuchnio A, Peric A, Moens S, Nys K, De Bock K, Quaegebeur A, Schoors S, Georgiadou M, Wouters J, Vinckier S, Vankelecom H, Garmyn M, Vion AC, Radtke $\mathrm{F}$, Boulanger $\mathrm{C}$, et al. Tumor vessel normalization by chloroquine independent of autophagy. Cancer cell. 2014; 26:190-206.

35. Choi H, Charnsangavej C, Faria SC, Macapinlac HA, Burgess MA, Patel SR, Chen LL, Podoloff DA and Benjamin RS. Correlation of computed tomography and positron emission tomography in patients with metastatic gastrointestinal stromal tumor treated at a single institution with imatinib mesylate: proposal of new computed tomography response criteria. J Clin Oncol. 2007; 25:17531759.

36. Mason WP, Macneil M, Kavan P, Easaw J, Macdonald D, Thiessen B, Urva S, Lwin Z, McIntosh L and Eisenhauer E. A phase I study of temozolomide and everolimus (RAD001) in patients with newly diagnosed and progressive glioblastoma either receiving or not receiving enzyme-inducing anticonvulsants: an NCIC CTG study. Investigational new drugs. 2012; 30:2344-2351.

37. Sotelo J, Briceno E and Lopez-Gonzalez MA. Adding chloroquine to conventional treatment for glioblastoma multiforme: a randomized, double-blind, placebo-controlled trial. Annals of internal medicine. 2006; 144:337-343.

38. Kim SJ, Kang HJ, Kim JS, Eom HS, Huh J, Ko YH, Lee J, Yim DS, Lee SY, Park WS, Yang WI, Lee SS, Suh $\mathrm{C}$ and Kim WS. A phase I study of everolimus and CHOP in newly diagnosed peripheral T-cell lymphomas. Investigational new drugs. 2013; 31:1514-1521.

39. Schuetze SM, Zhao L, Chugh R, Thomas DG, Lucas DR, 
Metko G, Zalupski MM and Baker LH. Results of a phase II study of sirolimus and cyclophosphamide in patients with advanced sarcoma. European journal of cancer. 2012; 48:1347-1353.

40. Andre F, O’Regan R, Ozguroglu M, Toi M, Xu B, Jerusalem G, Masuda N, Wilks S, Arena F, Isaacs C, Yap YS, Papai Z, Lang I, Armstrong A, Lerzo G, White M, et al. Everolimus for women with trastuzumab-resistant, HER2-positive, advanced breast cancer (BOLERO-3): a randomised, double-blind, placebo-controlled phase 3 trial. The Lancet Oncology. 2014; 15:580-591.

41. Goldberg SB, Supko JG, Neal JW, Muzikansky A, Digumarthy S, Fidias P, Temel JS, Heist RS, Shaw AT, McCarthy PO, Lynch TJ, Sharma S, Settleman JE and Sequist LV. A phase I study of erlotinib and hydroxychloroquine in advanced non-small-cell lung cancer. Journal of thoracic oncology : official publication of the International Association for the Study of Lung Cancer. 2012; 7:1602-1608.

42. Sun JM, Kim JR, Do IG, Lee SY, Lee J, Choi YL, Ahn JS, Ahn MJ and Park K. A phase-1b study of everolimus plus paclitaxel in patients with small-cell lung cancer. British journal of cancer. 2013; 109:1482-1487.

43. Werner D, Atmaca A, Pauligk C, Pustowka A, Jager E and Al-Batran SE. Phase I study of everolimus and mitomycin $\mathrm{C}$ for patients with metastatic esophagogastric adenocarcinoma. Cancer medicine. 2013; 2:325-333.

44. Fury MG, Sherman E, Ho AL, Xiao H, Tsai F, Nwankwo O, Sima C, Heguy A, Katabi N, Haque S and Pfister DG. A phase 1 study of everolimus plus docetaxel plus cisplatin as induction chemotherapy for patients with locally and/or regionally advanced head and neck cancer. Cancer. 2013; 119:1823-1831.

45. Kumar $P$ and Banik S. Pharmacotherapy options in rheumatoid arthritis. Clin Med Insights Arthritis Musculoskelet Disord. 2013; 6:35-43.

46. MacDonald AS. A worldwide, phase III, randomized, controlled, safety and efficacy study of a sirolimus/ cyclosporine regimen for prevention of acute rejection in recipients of primary mismatched renal allografts. Transplantation. 2001; 71:271-280.

47. McCormack FX, Inoue Y, Moss J, Singer LG, Strange C, Nakata K, Barker AF, Chapman JT, Brantly ML, Stocks JM, Brown KK, Lynch JP, 3rd, Goldberg HJ, Young LR, Kinder BW, Downey GP, et al. Efficacy and safety of sirolimus in lymphangioleiomyomatosis. N Engl J Med. 2011; 364:1595-1606.

48. Martinez-Outschoorn UE, Whitaker-Menezes D, Pavlides S, Chiavarina B, Bonuccelli G, Casey T, Tsirigos A, Migneco G, Witkiewicz A, Balliet R, Mercier I, Wang C, Flomenberg N, Howell A, Lin Z, Caro J, et al. The autophagic tumor stroma model of cancer or "batteryoperated tumor growth": A simple solution to the autophagy paradox. Cell Cycle. 2010; 9:4297-4306. 